\title{
DETERMINATION OF DOCOSAHEXAENOIC ACID IN INFANT FORMULAS WITH GAS CHROMATOGRAPHY
}

\author{
HARMITA HARMITA*, UMAR MANSUR, STEPHANIE STEPHANIE
}

\section{ABSTRACT}

Objective: Docosahexaenoic acid (DHA) is important for the development of infant's nervous and visual system because it is a major fatty acid in brain and retina phospholipids. However, the benefit of adding DHA in infant formulas is still controversial. The over intake of DHA should be considered because of its side effect. The aim of this study was to get a valid analysis method of DHA using gas chromatography (GC) to determine the concentration of DHA in infant formula.

Method: The milk fat was extracted in chloroform-methanol (1:2), continued with methylated in methanol-toluene (4:1) with acetyl chloride, and finally, injected to GC.

Result: The GC conditions were as follows: Injector temperature was $230^{\circ} \mathrm{C}$, detector temperature was $250^{\circ} \mathrm{C}$, oven temperature was programmed to increase from $130^{\circ} \mathrm{C}$ to $230^{\circ} \mathrm{C}$ by $2^{\circ} \mathrm{C} / \mathrm{min}$ and held for $20 \mathrm{~min}$, helium flow rate was $2.00 \mathrm{ml} / \mathrm{min}$, and split ratio was $1: 3$. This method had passed the precision and recovery evaluation. The result of DHA determination in five infant formula samples was $27.49 \pm 0.62 \mathrm{mg} / 100 \mathrm{~g}, 31.14 \pm 0.43 \mathrm{mg} / 100 \mathrm{~g}$, $11.83 \pm 0.38 \mathrm{mg} / 100 \mathrm{~g}, 19.34 \pm 0.58 \mathrm{mg} / 100 \mathrm{~g}$, and $45.87 \pm 0.42 \mathrm{mg} / 100 \mathrm{~g}$.

Conclusion: The method was valid and successfully applied to determine of DHA in infant formula.

Keywords: Docosahexaenoic acid, Gas chromatography, Infant formula.

(C) 2018 The Authors. Published by Innovare Academic Sciences Pvt Ltd. This is an open access article under the CC BY license (http://creativecommons. org/licenses/by/4. 0/) DOI: http://dx.doi.org/10.22159/ajpcr.2018.v11i3.23530

\section{INTRODUCTION}

Quality of human being determined by the early growth and development. The right intake of nutrients is essential for the optimal development of genetic potency. The nutrients must be given correctly both the quality and the quantity $[1,2]$. Mistakes in feeding will affect the quality of human being in the future. It is mainly related to the growth and development of vital organs, especially the brain that mostly grows fast during the last trimester of pregnancy and $1^{\text {st }}$ months of life. This growing brain needs perfect nutrients intake [3].

Docosahexaenoic acid (DHA) is a major fatty acid in brain and retina phospholipids [4]. It has important functional membrane and cellular properties of neural tissue [5]. Human milk contains DHA, whereas infant formula, which made from cow milk, has no DHA. To fulfil the necessity of DHA as essential nutrient, DHA is added to infant formulas [3], but the benefit of DHA in infant formulas is still controversial [1].

Over intake of DHA can inhibit the formation of arachidonic acid and also compete with arachidonic acid for the cyclooxygenase, and thus reduce the formation of prostaglandin Histamine 2 and Histamine 3 , thromboxane, and leukotriene that can inhibit inflammatory and immune response, which cause longer time of bleeding and decrease renin that has important role in renal regulatory [5].

The analysis method of DHA needed to avoid improper DHA concentration in infant formulas. The analysis method of DHA is not simple. First, the milk fat has to be separated from other components such as carbohydrate and protein. Then, before injected to GC, the fat has to be converted to methyl ester [6,7]. The extraction and esterification steps must be carried out carefully to avoid the losses of
DHA, because of these complicated steps, the analysis method of DHA needs to be studied.

\section{METHODS}

\section{Equipments}

Gas chromatography (GC) (Shimadzu GC-17A), VB-wax capillary column $(60 \mathrm{~m} \times 0.32 \mathrm{~mm} \times 0.25 \mu \mathrm{m})$ equipped with a flame-ionized detector, helium as carrier gas, Class GC solution data processor, and microsyringe $10 \mu \mathrm{l}$ (SGE), oven, centrifuge (Kubota 6800 and 5100), analytic, borosilicate glass tubes with feflon-lined screw-caps (100 mm $\times 13 \mathrm{~mm}$ ), centrifugation tubes, vortex, micropipette (Socorex), and other glass-wares for quantitative analysis were commonly used.

\section{Materials}

DHA (Sigma, CAS no. 6217545), DHA oil (Tama Biochemical Co. Ltd. Lot 611151), methanol p.a. (Merck), chloroform p.a. (Merck), toluene p.a. (Merck), hexane p.a. (Merck), acetyl chloride for synthesis (Merck), sodium chloride p.a. (Merck), and potassium carbonate p.a. (Merck) were used.

\section{Determination of GC analysis condition}

About $25 \mathrm{mg}$ of DHA standard was precisely weighed, then diluted with hexane until $10.0 \mathrm{ml}, 300 \mu \mathrm{l}$ of this $2500 \mu \mathrm{g} / \mathrm{ml}$ DHA standard solution were placed to teflon-lined caps reaction tube, dried under nitrogen stream, and was submitted to the esterification procedure described below. $1.0 \mu \mathrm{l}$ of the aliquot of the upper toluene phase was injected into the chromatograph. The experiments to determine the GC analysis were done in isothermal condition and by temperature programmed. Elusion with isothermal condition was done by holding the temperature at $200^{\circ} \mathrm{C}$ with helium flow rate $1.35 \mathrm{ml} / \mathrm{min}$. Elusion with temperature programmed was done by variation of the starting temperature at 120,130 , and $140^{\circ} \mathrm{C}$ and also a variation of flow rate at $1.35,1.80$, and 
$2.00 \mathrm{ml} / \mathrm{min}$. The column temperature was increased $2^{\circ} \mathrm{C} /$ min until $230^{\circ} \mathrm{C}$ then was held at $230^{\circ} \mathrm{C}$ for $20 \mathrm{~min}$. The split ratio was $1: 3$. The injector port temperature was $230^{\circ} \mathrm{C}$ and the detector was $250^{\circ} \mathrm{C}$. The condition that had the highest value of theoretical plates and the lowest value of HETP were chosen on the next steps of this research [8].

\section{Determination of DHA concentration in DHA oil}

$50 \mu \mathrm{l}, 100 \mu \mathrm{l}, 200 \mu \mathrm{l}, 300 \mu \mathrm{l}, 400 \mu \mathrm{l}$, and $500 \mu \mathrm{l}$ of the $2500 \mu \mathrm{g} / \mathrm{ml}$ DHA standard solution were placed to Teflon-lined caps reaction tubes, dried under nitrogen stream, and were submitted to the esterification procedure described below. $1.0 \mu \mathrm{l}$ of the aliquot of the upper toluene phase was injected into the chromatograph. Each area of DHA chromatograph was used to make calibration curve, then calculated the regression equation.

About $25 \mathrm{mg}$ of DHA oil was precisely weighed, then diluted with hexane until $25.0 \mathrm{ml}, 300 \mu \mathrm{l}$ of this $10000 \mu \mathrm{g} / \mathrm{ml}$ DHA oil solution were placed to Teflon-lined caps reaction tube, dried under nitrogen stream, and was submitted to the esterification procedure described below. $1.0 \mu \mathrm{l}$ of the aliquot of the upper toluene phase was injected to the chromatograph with chosen analysis condition. The concentration of DHA was calculated by inserting the area of DHA chromatograph to the calibration curve equation. This experiment was repeated twice.

Linearity test, calibration curve, and calculation of limit of detection (LOD) and limit of quantification (LOQ)

$50 \mu \mathrm{l}, 100 \mu \mathrm{l}, 200 \mu \mathrm{l}, 300 \mu \mathrm{l}, 400 \mu \mathrm{l}, 500 \mu \mathrm{l}$, and $600 \mu \mathrm{l}$ of the $10000 \mu \mathrm{g} / \mathrm{ml}$ DHA oil solution were placed to Teflon-lined caps reaction tubes, dried under nitrogen stream, and were submitted to the esterification procedure described below. $1.0 \mu \mathrm{l}$ of the aliquot of the upper toluene phase was injected into the chromatograph. Each area of DHA chromatograph was used to make calibration curve and then calculated the regression equation. Linearity was showed by the value of the coefficient of correlation between DHA concentration and area of DHA chromatogram.

\section{Precision test}

$100 \mu \mathrm{l}, 200 \mu \mathrm{l}$, and $300 \mu \mathrm{l}$ of $10000 \mu \mathrm{g} / \mathrm{ml}$ DHA oil solution were put into Teflon-lined caps reaction tubes, dried under nitrogen stream, and were submitted to the esterification procedure described below. $1.0 \mu \mathrm{l}$ of the aliquot of the upper toluene phase was injected to the chromatograph. Each concentration was repeated 5 times. Precision calculated as the coefficient of variation.

\section{Recovery test}

About $90 \mathrm{mg}$ of DHA oil was precisely weighed, then diluted with hexane until $10.0 \mathrm{ml} .2 \mathrm{~g}$ of milk that contain no DHA were put into each $50 \mathrm{ml}$ centrifugation tube, and $200 \mu \mathrm{l}, 250 \mu \mathrm{l}$, and $300 \mu \mathrm{l}$ of $90000 \mu \mathrm{g} / \mathrm{ml}$ DHA oil solution were added into each tube. Then, the mixtures were treated for the extraction and esterification procedure described below. $1.0 \mu \mathrm{l}$ of the aliquot of the upper toluene phase was injected into the chromatograph. Each concentration was repeated twice. Recovery calculated by comparing the obtained concentration to the actual concentration of DHA added.

\section{Extraction of milk fat}

About $2 \mathrm{~g}$ of milk sample was put into centrifugation tube. $15 \mathrm{ml}$ chloroform-methanol $(1: 2)$ was added into it $[9,10]$, and the tube was shaken well for about $15 \mathrm{~min}$ in orbital shaker. Then, $5 \mathrm{ml}$ of chloroform was added and vortex well. Next, $5 \mathrm{ml}$ of $9 \%$ sodium chloride solution was added and vortexed well. After that, the tube was centrifuged at $3000 \mathrm{rpm}$ for $5 \mathrm{~min}$. It would form 3 layers. The upper phase and middle phase were discarded slowly and carefully. The bottom phase was washed with $10 \mathrm{ml}$ of methanol-saline solution (9:10) and vortexed well. The bottom phase was collected into Erlenmeyer, and the chloroform was vaporized by heating on the water bath. The fat extract was determined gravimetrically.

\section{RESULTS AND DISCUSSION}

\section{GC analysis condition}

The obtain GC analysis conditions were as follows: Injector temperature was $230^{\circ} \mathrm{C}$, detector temperature was $250^{\circ} \mathrm{C}$, oven temperature was programmed to increase from $130^{\circ} \mathrm{C}$ to $230^{\circ} \mathrm{C}$ by $2^{\circ} \mathrm{C} / \mathrm{min}$ and held for $20 \mathrm{~min}$, helium flow rate was $2.00 \mathrm{ml} / \mathrm{min}$, and split ratio was $1: 3$. Among the other condition, it had the highest value of theoretical plates or the lowest value of HETP [11]. The results clearly showed in Table 1 and Fig. 1.

\section{Determination of DHA in DHA oil}

From triple experiments, the average DHA concentration in DHA oil was $22.76 \%$. The measurement of DHA in DHA oil was plotted to the linear regression equation of the calibration curve of DHA standard. The equation of calibration curve of DHA standard was $y=-3349.6516+66.8654 x$, with a value of the coefficient of correlation was 0.9999 .

\section{Esterification of fat}

The fat extract was put into Teflon-lined caps reaction tube and dissolved in $0.40 \mathrm{ml}$ of toluene and $1.6 \mathrm{ml}$ of methanol, then it was shaken well. $0.2 \mathrm{ml}$ of acetyl chloride was added slowly over $1 \mathrm{~min}$ while the tube was shaken slowly. Tube was closed tightly and methanolysis was conducted at $100^{\circ} \mathrm{C}$ for $1 \mathrm{~h}$. After tube had been cooled in water, $5 \mathrm{ml}$ of $6 \% \mathrm{~K}_{2} \mathrm{CO}_{3}$ solution was added slowly to stop the reaction and neutralize the mixture. The tubes were shaken and centrifuged, and an aliquot of the toluene upper phase was injected into the chromatograph. The correlation was 0.9993 . The result clearly is presented in Table 2 and 3.

Linearity test, calibration curve, and calculation of LOD and LOQ The linear regression equation of calibration curve was $y=-356.1393+67.1206 x$, with a value of the coefficient of correlation

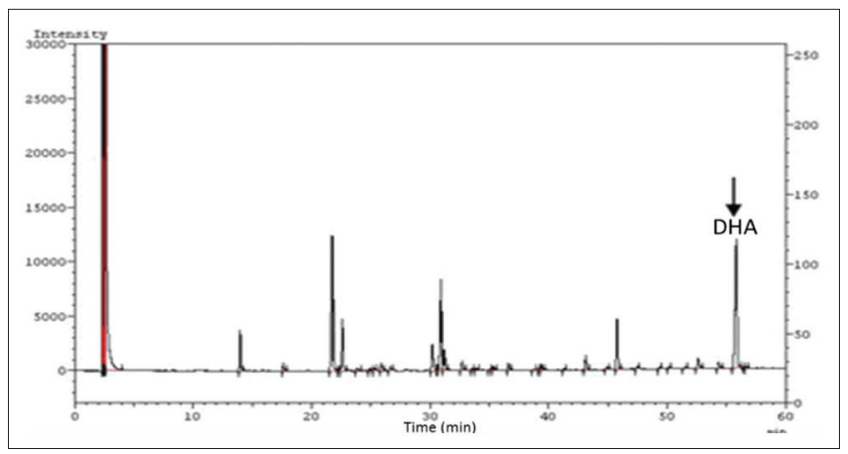

Fig. 1: Chromatogram of docosahexaenoic acid oil

Table 1: Determination of gas chromatography analysis condition

\begin{tabular}{llllll}
\hline Condition & Starting $\left({ }^{\circ} \mathbf{C}\right)$ & Flow rate $(\mathbf{m L} / \mathbf{m i n})$ & Time retention $(\mathbf{m i n})$ & Theoretical plates & HETP \\
\hline Programmed & 120 & 1.35 & 68.200 & 605654.984 & 0.00991 \\
& 120 & 1.80 & 63.468 & 686485.845 & 0.00874 \\
& 120 & 2.00 & 62.116 & 671114.224 & 0.00894 \\
Isothermal & 130 & 1.35 & 62.686 & 638605.624 & 0.00934 \\
& 140 & 1.80 & 56.731 & 587010.084 & 0.01022 \\
& 140 & 2.00 & 52.439 & 523527.926 & 0.01146 \\
& 140 & 1.35 & 68.280 & 501615.256 & 0.01196 \\
\hline
\end{tabular}


was 0.9999 . With the obtained value of the coefficient of correlation, the calibration curve of DHA concluded linear. LOD was $74.33 \mu \mathrm{g} / \mathrm{g}$ and LOQ was $247.77 \mu \mathrm{g} / \mathrm{g}$. These values were still below the smallest concentration in the calibration curve.

\section{Precision test}

In this research, precision test was conducted at low, medium, and high concentration of calibration curve. The concentrations were $689.95 \mu \mathrm{g} / \mathrm{g}$, $2051.45 \mu \mathrm{g} / \mathrm{g}$, and $4066.25 \mu \mathrm{g} / \mathrm{g}$. The precision of esterification and

Table 2: Result of DHA standard measurements for calibration curve

\begin{tabular}{ll}
\hline Concentration $(\boldsymbol{\mu g} / \mathrm{g})$ & Area $(\boldsymbol{\mu V} / \mathbf{s})$ \\
\hline 388.58 & 24495 \\
776.85 & 50342 \\
1552.50 & 99519 \\
2326.94 & 146129 \\
3100.19 & 203598 \\
3872.23 & 259360 \\
\hline
\end{tabular}

DHA: Docosahexaenoic acid

Table 3: Result of DHA determination in DHA oil

\begin{tabular}{llll}
\hline $\begin{array}{l}\text { Area } \\
(\boldsymbol{\mu V} / \mathbf{s})\end{array}$ & $\begin{array}{l}\text { Concentration } \\
(\boldsymbol{\mu g} / \mathbf{m l})\end{array}$ & $\begin{array}{l}\text { DHA } \\
\text { concentration (\%) }\end{array}$ & $\begin{array}{l}\text { Average } \\
\text { concentration (\%) }\end{array}$ \\
\hline 133947 & 2389.711 & 23.78 & \\
133956 & 2389.868 & 23.78 & 22.76 \\
133573 & 2383.201 & 23.72 & \\
\hline
\end{tabular}

DHA: Docosahexaenoic acid chromatography analysis of DHA was good with the coefficient of variations of each concentration, respectively, was $1.73 \%, 1.46 \%$, and $1.85 \%$. Since the coefficient of variations was below $2 \%$, this method concluded having a precise result. The result clearly is shown in Table 4.

\section{Recovery test}

Recovery test was conducted using absolute method, which calculated as the percentage of recovery of DHA was added to the blank milk. The amount of DHA that added to the blank milk was $0.025 \%$ from total weight of milk. This evaluation had a satisfactory result with the percentage of recovery of DHA was $96.40 \%$. The recovery requirement which has concentration below $0.1 \%$ is $95.0-105.0 \%$. With this result, it concluded that the analysis method used was accurate enough. The result clearly showed in Table 5.

\section{Result of DHA determination in some infant formulas}

After determining five different samples of infant formulas, three samples had DHA concentration significantly higher than the concentration written in the packaging label. DHA concentrations in five samples, respectively, were $27.49 \pm 0.62 \mathrm{mg} / 100 \mathrm{~g}, 31.14 \pm 0.43 \mathrm{mg} / 100 \mathrm{~g}, 11.83 \pm 0.38 \mathrm{mg} / 100 \mathrm{~g}$, $19.34 \pm 0.58 \mathrm{mg} / 100 \mathrm{~g}$, and $45.87 \pm 0.42 \mathrm{mg} / 100 \mathrm{~g}$.

Sample A had DHA 8.36\% less than the concentration written in packaging label, sample B had 55.68\% more DHA, sample C had 51.70\% more DHA, sample D had $136.44 \%$ more DHA, and sample E had 5.44\% more DHA than the concentration written in packaging label. The result clearly showed in Table 6 .

\section{CONCLUSION}

The optimum GC analysis conditions were as follows: Injector temperature was $230^{\circ} \mathrm{C}$, detector temperature was $250^{\circ} \mathrm{C}$, oven

Table 4: Result of precision test

\begin{tabular}{|c|c|c|c|c|c|}
\hline Concentration $(\mu \mathrm{g} / \mathrm{g})$ & Area $(\mu \mathrm{V} / \mathrm{s})$ & $\begin{array}{l}\text { Measured } \\
\text { Concentration }(\mu \mathrm{g} / \mathrm{g})\end{array}$ & $\begin{array}{l}\text { Mean measured } \\
\text { Concentration }(\mu \mathrm{g} / \mathrm{g})\end{array}$ & $\begin{array}{l}\text { Standard of } \\
\text { deviation }\end{array}$ & $\begin{array}{l}\text { Coefficient of } \\
\text { variation }(\%)\end{array}$ \\
\hline & 49277 & 740,338 & & & \\
\hline & 47014 & 706,118 & & & \\
\hline \multirow[t]{6}{*}{689.95} & 48238 & 724,627 & 721.164 & 12.4506 & 1.73 \\
\hline & 47500 & 713,467 & & & \\
\hline & 47603 & 715,010 & & & \\
\hline & 48662 & 731,038 & & & \\
\hline & 130731 & 1972,039 & & & \\
\hline & 133947 & 2020,669 & & & \\
\hline \multirow[t]{6}{*}{2051.45} & 133956 & 2020,805 & 1975.261 & 28.7647 & 1.46 \\
\hline & 131826 & 1988,597 & & & \\
\hline & 129315 & 1950,627 & & & \\
\hline & 133573 & 2015,014 & & & \\
\hline & 271621 & 4102,496 & & & \\
\hline & 273395 & 4129,322 & & & \\
\hline \multirow[t]{4}{*}{4066.25} & 282373 & 4265,082 & 4110.744 & 75.5626 & 1.84 \\
\hline & 280094 & 4230,620 & & & \\
\hline & 269217 & 4066,144 & & & \\
\hline & 276658 & 4178,663 & & & \\
\hline
\end{tabular}

Table 5: Result of recovery test

\begin{tabular}{llll}
\hline \multirow{2}{*}{ Added DHA $(\boldsymbol{\mu g})$} & \multicolumn{2}{l}{ Result of DHA determinations } & Mean Recovery (\%) \\
\cline { 2 - 4 } & Measured $(\boldsymbol{\mu g})$ & Recovery $(\%)$ & 96.27 \\
419.694 & 407.928 & 97.20 & 96.86 \\
524.618 & 402.315 & 95.74 & 96.05 \\
& 401.834 & 97.77 & 96.88 \\
629.542 & 512.903 & 95.30 & 95.09 \\
\end{tabular}

DHA: Docosahexaenoic acid 
Table 6: Result of determination in some infant formulas

\begin{tabular}{|c|c|c|c|}
\hline \multirow[t]{2}{*}{ Sample } & \multicolumn{3}{|l|}{ Result of DHA determination } \\
\hline & Concentration $(\mathrm{mg} / \mathbf{1 0 0} \mathrm{g})$ & Mean concentration (mg/100 g) & Concentration written in the packaging label $(\mathrm{mg} / \mathbf{1 0 0} \mathrm{g})$ \\
\hline \multirow{4}{*}{ A } & 27.46 & & \\
\hline & 26.89 & 27.46 & 30.0 \\
\hline & 28.13 & & \\
\hline & 31.46 & & \\
\hline \multirow[t]{3}{*}{ B } & 30.64 & 31.14 & 20.0 \\
\hline & 31.31 & & \\
\hline & 11.96 & & \\
\hline \multirow[t]{3}{*}{$\mathrm{C}$} & 11.41 & 11.83 & 7.8 \\
\hline & 12.14 & & \\
\hline & 19.98 & & \\
\hline \multirow[t]{3}{*}{$\mathrm{D}$} & 19.21 & 19.34 & 8.2 \\
\hline & 18.83 & & \\
\hline & 45.69 & & \\
\hline \multirow[t]{2}{*}{$\mathrm{E}$} & 45.57 & 45.87 & 43.5 \\
\hline & 46.34 & & \\
\hline
\end{tabular}

DHA: Docosahexaenoic acid

temperature was programmed to increase from $130^{\circ} \mathrm{C}$ to $230^{\circ} \mathrm{C}$ by $2^{\circ} \mathrm{C} / \mathrm{min}$ and held for $20 \mathrm{~min}$, helium flow rate was $2.00 \mathrm{ml} / \mathrm{min}$, and split ratio was $1: 3$. The extraction, esterification, and chromatography method of DHA determination used in this research had passed the linearity, precision, and recovery evaluation so that this method can be applied to determine DHA in infant formula. DHA concentrations in five infant formula samples, respectively, were $27.49 \pm 0.62 \mathrm{mg} / 100 \mathrm{~g}$, $31.14 \pm 0.43 \mathrm{mg} / 100 \mathrm{~g}, 11.83 \pm 0.38 \mathrm{mg} / 100 \mathrm{~g}, 19.34 \pm 0.58 \mathrm{mg} / 100 \mathrm{~g}$, and $45.87 \pm 0.42 \mathrm{mg} / 100 \mathrm{~g}$.

\section{AUTHORS CONTRIBUTIONS}

All the author have contributed equally.

\section{CONFLICT OF INTERESTS}

Declared none.

\section{REFERENCES}

1. Judarwanto W. Kontroversi Penambahan AA dan DHA pada Vitamin dan Makanan Bayi. Available from: http://www.eppa.multiply.com/ journal/item/115. [Last cited on 2016 Sep 10].

2. Nikhade R, Deshpande SA. Formulation evaluation and validation of ophthalmic emulsion of docosahexaenoic acid. Int J Pharmacol Res 2014;4:67-70
3. Hidajat B. Penambahan DHA dan AA pada Bayi: Peran dan Manfaatnya. Available from: http://www.pediatrik.com/ilmiah popular/2006 0220-ozgay7-ilmiah_popular.doc. [Last cited on 2016 Sep 08].

4. Willatts P, Forsyth JS, DiModugno MK, Varma S, Colvin M. Effect of long-chain polyunsaturated fatty acids in infant formula on problem solving at 10 months of age. Lancet 1998;352:688-91.

5. WHO. Fats and Oil in Human Nutrition. Report of a Joint Expert Consultation. Rome: WHO; 1993. p. 19-26.

6. Skoog DA, Donald MW, James FH, Stanly RC. Fundamentals of Analytical Chemistry. $9^{\text {th }}$ ed. Brookly (USA): Thomson Learning Inc; 2014.

7. Bligh EG, Dyer WJ. A rapid method for total lipid extraction and purification. Can J Biochem Physiol 1959;37:911-7.

8. Sahoo S, Jena S, Sahoo A, Ray A, Sudan I. GC-MS profile of in vivo and in vitro shoots of cleome gynandra L. Int J Pharm Pharm Sci 2017;9:21-6.

9. Lepage G, Roy CC. Direct transesterification of all classes of lipids in a one-step reaction. J Lipid Res 1986;27:114-20.

10. Or-Rashid MM, Odongo NE, Wright TC, McBride BW. Fatty acid profile of bovine milk naturally enhanced with docosahexaenoic acid. J Agric Food Chem 2009;57:1366-71.

11. Nongalleima K, Ajungla T, Chingakham BS. GC-MS based metabolic profiling of essential oil of Citrus macroptera montruz leaves and peel, assessment of in vitro antioxidant and anti-inflammatory activity. Int $\mathrm{J}$ Pharm Pharm Sci 2017;9:107-14. 